\title{
ACADEMIC ACHIEVEMENT AND SELF CONFIDENCE OF WORKING AND NON-WORKING MOTHERS OF KASHMIR
}

\author{
Sajad Hussain Kawa, Dr.Gungan.Rajput \\ Research Scholar, Dept. of. Education, Glocal University, Saharanpur, U.P., \\ India \\ Research Guide, Dept. of. Education, Glocal University, Saharanpur, U.P., \\ India
}

Email: sh453170@gmail.com

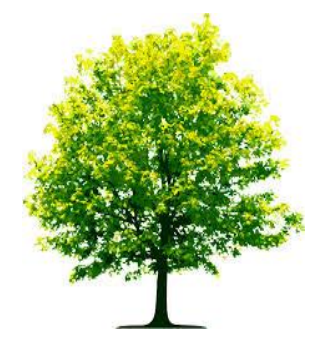

Keywords: Self-confidence, Academic Achievement, Working Mothers and Nonworking Mothers

\begin{abstract}
A B S T RA C T
The present study was undertaken to find out the self-confidence and academic achievement of children of working and nonworking mothers of Kashmir.800 children was selected as sample for the present study (in which 400 children of working mothers and 400 children of non-working mothers) by using simple random sampling technique. Rekha Gupta's Agnihotri Self confidence Inventory was used for data collection. For statistical analysis mean, SD, t-test and Correlation was used. The results of the study revealed that children of working mothers have found high self-confidence than the children of non-working mothers. The result also revealed that there is no significant difference between children of working and non-working mothers on academic achievement. It was also found that a positive correlation was found between self-confidence and academic achievement.
\end{abstract}

Citation: Sajad Hussain Kawa, Dr.Gungan.Rajput, (2019). Academic Achievement And Self Confidence of Working And Non-Working Mothers of Kashmir: International Journal of Advanced Multidisciplinary Scientific Research (IJAMSR) ISSN:2581-4281, 2 (2), February, 2019, \# Art.1220, pp 95-100 
IJAMSR 2 (2) www.ijamsr.com CrossRef: https://doi.org/10.31426/ijamsr.2019.2.2.1220

\section{International Journal of Advanced Multidisciplinary Scientific Research (IJAMSR) ISSN:2581-4281}

\section{Introduction}

Education in the largest sense is an act or an experience that has a formative effect on the mind, character or physical ability of an individual. In its technical sense, education is the process by which society deliberately transmits its accumulated knowledge, skills and values from one generation to another society. Education in real sense is to humanize humanity and to make life progressive cultured and civilized. It is very important for the progress of the individual and society. It is through education that man develops his thinking and reasoning, problem solving , intelligence and creativity and aptitude, positive sentiments and skills, good values and attitudes. Education is a dialogue between the past, present and the future, so that the coming generations receive the accumulated lessons of the heritage and carry it forward (UNESCO, 1998). Success which is generally seen as an internal ability within an individual is indeed also prejudiced by many external factors including the behavior of parents during childhood. Although the father is a significant role model, the role of mother in a child's growth is indubitable. In this reverence the influence of the profession of a mother, particularly, whether the mother is working or not becomes a central factor for scrutiny. The foremost distress is that maternal employment clearly confines the amount of instance dedicated to raising children. The involvement of the mothers is influential, the individuality of their children cannot be neglected, but an unparalleled figure of women, especially mothers, are inflating in the field of employment due to monetary obligation or in explore of individuality. This had piloted to a drastic shift in the conventional role of mother as a "care taker" to a "bread earner" and has changed child nurture goals and preparations. The outcomes of mother's employment of children have pessimistic and optimistic actions. Therefore, it's necessary to find out the diversity in psycho social disturbance of children of working and non working mothers. This will facilitate the employing mothers to develop the care given in the direction of their children. This will also assist them to contemplate on their emotional and behavioral personality. This in turn reproduces their personality enhancement.

Self-confidence is the thought that one will bring out in an accurate, perfect or wellorganized way. Self confidence is having selfsufficiency in oneself. Self-confidence can distantly be illustrated as the ability of a person to struggle. Developing self-confidence can provide you the inspiration to accept 
IJAMSR 2 (2) www.ijamsr.com CrossRef: https://doi.org/10.31426/ijamsr.2019.2.2.1220

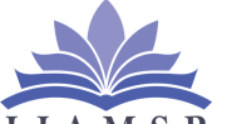

\section{International Journal of}

I J A M S R

\section{Advanced Multidisciplinary Scientific Research (IJAMSR) ISSN:2581-4281}

challenges and weaknesses, so as to acquire trust and understanding in an individual. Selfconfidence is an approach which permits individuals to have positive yet critical views of themselves and their circumstances. Selfconfident individual's belief their own abilities have a common way of control in their life's. Self confidence is vital to good psychological alteration, individual pleasure and efficient performance in children and adults. The name self confidence is used to demote to individual's judgement about them. Children with overall high ideas are certain about their attitude to achieve their objectives, scholastic competency and association with guardians and other people. Children with low self confidence, lean to be anxious about strange ideas and avoid attracting deliberation.

\section{Need and Importance}

Self confidence is an approach that you hold about yourself that let you to go forward and reach your aims. The most imperative thing to defend is confidence and faith in the person. It is the groundwork of all personal accomplishments. You can achieve higher goals in life when you believe in yourself. Self confidence is frequently a most essential asset than ability, knowledge or even experience. Self confidence can alter your whole life to the better, but not having self confidence will absolutely have a negative effect on your every part of life. Self confidence is an important factor for better academic excellence. Building self confidence in students is one of the most significant both for parents as well as educationists to set good environment for learning, which is a key constituent to high achievement. Building confidence in children can help in preventing student dropouts, ensure children maintain their love for learning and help them to achieve their dreams and goals.

After making the survey of the related literature, it is obvious that many studies have been conducted in various areas, but no such study has been conducted on the "Self Confidence of children of working and nonworking mothers of Kashmir." In this background the researcher is interested to work on present study. The problem under study is a humble attempt to assess the Self Confidence of children of working and non-working mothers. The research is very useful and helpful for educationists, policy makers, planners, teachers, administrators, and especially to the parents. 
IJAMSR 2 (2) www.ijamsr.com CrossRef: https://doi.org/10.31426/ijamsr.2019.2.2.1220

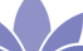

I J A M S R

\section{International Journal of Advanced Multidisciplinary Scientific Research (IJAMSR) ISSN:2581-4281}

\section{Objectives}

The following objectives were formulated for the present investigation:

a) To study and compare children of working and non-working mothers on self confidence.

b) To study and compare children of working and non-working mothers on academic achievement.

\section{Hypotheses}

The following hypotheses were formulated for the present investigation:

a) There is a significant difference between children of working and nonworking mothers on self confidence.

b) There is a significant difference between children of working and nonworking mothers on academic achievement.

\section{Academic Achievement}

Academic achievement in the present study means the aggregate marks obtained by the sample students in all the subjects in their $8^{\text {th }}$ class examination conducted by District Institute of Education and Training (DIET).

\section{Working mothers}

Working mothers in the present study referred to educated women with educational qualification as $12^{\text {th }}$ and above, and are engaged in any government, semi-government or private organization

\section{Methodology}

The present study explored by using descriptive methods.

\section{Plan And Procedure:}

\section{Design of the Sample}

The sample for the present study consists of 800 children, (children of working mothers 400 and children of non-working mothers, 400 of Kashmir) drawn from various high and higher secondary school students of district Srinagar, Anantnag, Budgam and Pulwama.

\begin{tabular}{|l|c|}
\hline Group & Respondents \\
\hline Children of working mothers & 400 \\
\hline $\begin{array}{l}\text { Children of non-working } \\
\text { mothers }\end{array}$ & 400 \\
\hline Total & 800 \\
\hline
\end{tabular}


IJAMSR 2 (2) www.ijamsr.com CrossRef: https://doi.org/10.31426/ijamsr.2019.2.2.1220

\section{International Journal of Advanced Multidisciplinary Scientific Research (IJAMSR) ISSN:2581-4281}

\section{Tools}

The following tools were used for the present study-

a) .Self Confidence inventory by Rekha Gupta Agnihotri.

Academic achievement in the present study means the aggregate marks obtained by the sample subjects in all the subjects in their 8th class.

\section{Statistical Analysis}

After collecting the data, it was statistically analyzed by computing mean, S.D., t-test and Correlation.

Table 1: Showing mean comparison between children of working and non-working mothers on Self Confidence ( $\mathrm{N}=300$ in each group)

\begin{tabular}{|c|c|c|c|c|c|}
\hline $\begin{array}{l}\text { Variab } \\
\text { le }\end{array}$ & Group & $\begin{array}{l}\mathrm{Me} \\
\text { an }\end{array}$ & $\begin{array}{l}\text { Std. } \\
\text { Deviati } \\
\text { on }\end{array}$ & $\begin{array}{l}\text { t- } \\
\text { valu } \\
e\end{array}$ & $\begin{array}{l}\text { Level } \\
\text { of } \\
\text { Signifi } \\
\text { cance }\end{array}$ \\
\hline \multirow{2}{*}{$\begin{array}{l}\text { Self } \\
\text { Confide } \\
\text { nce }\end{array}$} & $\begin{array}{l}\text { Children } \\
\text { of } \\
\text { working } \\
\text { mothers }\end{array}$ & $\begin{array}{l}26 . \\
57\end{array}$ & 6.95 & \multirow{2}{*}{4.61} & \multirow{2}{*}{$\begin{array}{l}\text { Signifi } \\
\text { cant at } \\
0.01 \\
\text { level }\end{array}$} \\
\hline & $\begin{array}{l}\text { Children } \\
\text { of non- } \\
\text { working } \\
\text { mothers }\end{array}$ & $\begin{array}{l}23 . \\
92\end{array}$ & 7.10 & & \\
\hline
\end{tabular}

The perusal of the above table displays the comparison between children of working and non-working mothers on self-confidence. The obtained $t$. The value is (4.61) which show that there is a significant difference between children of working and non-working mothers on self-confidence which is significant at 0.01 level. It indicates that children of working mothers have high self-confidence than the children of non-working mothers. Children of working. 
IJAMSR 2 (2) www.ijamsr.com CrossRef: https://doi.org/10.31426/ijamsr.2019.2.2.1220

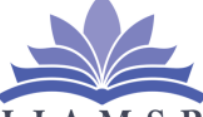

\section{International Journal of Advanced Multidisciplinary Scientific Research (IJAMSR) ISSN:2581-4281}

\section{Major Findings}

The major findings of the present study are as under:

a) The results depicted that there is a significant difference between children of working and non-working mothers on self-confidence. It was also found that children of working mothers have high self-confidence than the children of non working mothers. Children of working mothers show more confidence and are able to accept challenges and weaknesses readily.

b) The results indicated that there is no significant difference between children of working and non working mothers on academic achievement. Both the groups get equal opportunity to achieve educational goals.

\section{References}

1) Navedita and Rani, $P$ (2017) A comparative study of women social freedom in relation to self-confidence of university students in Sirsa district. International Journal of Research in Economics and Social Sciences, 7(5): 14-19.

2) Saini, $M$ (2016) A study of self-confidence and academic achievement of high school students in relation to certain socio-demographic variables. International Journal of research in Economics and social Sciences, 6(6): 38-48.

3) Makrani, G (2016) A comparative study of selfconfidence level in graduate and higher secondary students among Sabarkantha- North Gujarat. KCG - Portal of Journals, (10): 1-5.

4) Verma, R. and Kumari, S (2016) Effect of selfconfidence on academic achievement of children at elementary stage. International Journal of Research, 5(1): 181-183.

5) Nidhi and Kolnala, A (2014) Effect of parental Encouragement on self-confidence of adolescents. Indian Journal of applied Research, 4(10): 520- 523.

6) Basvanna, M; (1975). Manual of self-confidence inventory, Varanasi, Rupa Psychological Centre, In: Manual of self-confidence inventory Ed: Agnihotri, Rekha (1987) National Psychological Coorporation.

7) Feroz (2018) Correlating self-esteem and academic outcomes. International Journal of Psychology and Behavioural Sciences, 18(2): $1-5$.

8) Kumar, V. R and Chamundeswari, $S$ (2015) Achievement motivation, study habits and academic achievement of students at the secondary level. International Journal of Emerging Research in Management and Technology, 4(10): 713.

9) Arbona, C (2000) The Development of Academic Achievement in School aged Children: precursors to Career Development. Handbook of Counselling Psychology ( $3^{\text {rd }}$ ed.): 270-307, New York: Wiley.

10) Best, J.W. (1989) Research in Education, New Delhi, Prentice Hall of Indian Private limited. 